\title{
Cerebral Non-Hodgkin Lymphoma
}

National Cancer Institute

\section{Source}

National Cancer Institute. Cerebral Non-Hodgkin Lymphoma. NCI Thesaurus. Code C7609.

A non-Hodgkin lymphoma that arises in the cerebral hemispheres as a primary lesion. 